\title{
Understanding capital market responses to government economic policy announcements: An event study on Indonesia's Economic Policy Package
}

\author{
Hari Gursida $^{\mathrm{a}}$ and Yohanes Indrayono ${ }^{\mathrm{a}^{*}}$
}

${ }^{a}$ Doctoral Program of Management Science, Universitas Pakuan, Bogor, Indonesia

\begin{tabular}{l}
\hline C H R O N I C L E \\
\hline Article history: \\
Received: May 12019 \\
Received in revised format: May \\
102019 \\
Accepted: June 5, 2019 \\
Available online: \\
June 7, 2019 \\
\hline Keywords: \\
Cumulative Abnormal Return \\
Indonesia Economic Policy Pack- \\
age \\
JCI \\
Indonesia Stock Exchange \\
Government policy
\end{tabular}

\section{A B S T R A C T}

\begin{abstract}
This paper investigates the changes in stock market returns before and after the announcement of a sample of three instalments, or 'volumes', (I, X, and XVI) of the Indonesian government's Economic Policy Package (EPP), between 2015 and 2017. It tracks Abnormal Return (AR) and Cumulative Abnormal Return (CAR) on the Composite Stock Price Index (JCI) and ten sectorial indices of the Indonesia Stock Exchange. By testing for the direction and significance of differences in AR and CAR, the paper aims to clarify whether those announcements provided sufficient informational content to sway prices. The study finds that the impact of the policy announcements was recorded primarily by individual sectors, but did not elicit a significant market-wide response. Moreover, the majority of economic sectors consistently reacted negatively. This shows that, overall, capital markets did not feel those government policies contain sufficient measures to remove obstacles to business activity.
\end{abstract}

\section{Introduction}

Economic activity is influenced by political decisions, both directly and indirectly. One impact of political decisions on economic activity might manifest through changes in stock prices, which in turn influences investors' decisions. In view of this, the type of response elicited from investors can be one way of testing the efficacy of government policy. The use of one such measure can be justified on grounds of market efficiency (Tandelilin, 2010). Indeed, capital market theory holds that markets process any new information - including government policy announcements - to achieve a new equilibrium position. This is made possible by the fact that markets aggregate information possessed by many investors, which is in turn incorporated into securities' prices as a consequence of investor competition (Berk et al., 2012; Huang \& Zhu, 2015). This study contributes to an understanding of stock market responses to new government policies, by undertaking an event study in connection to the announcement of a sample of three instalments of a package of economic measures issued by the Indonesian government between 2015 and 2017. Event studies are also useful to assess capital market efficiency in its semi-strong form, because they help reveal how quickly the market responds to the informational content of an announcement, or

* Corresponding author.

E-mail address: yindrayono@yahoo.com (Y. Indrayono) 
to news of particular events such as a new government policy (Samsul, 2016). Event studies examine the variation in stock prices both during and after an event, on the assumption that the total effect manifests beyond the discrete moment in which an event is announced, because stock prices adjust over time to attain a new equilibrium (Samsul, 2016). The event considered in this study is the announcement, by Indonesia's President Joko Widodo, of a new governmental Economic Policy Package (EPP), aiming to accelerate Indonesia's economic growth. The EPP has consisted of sixteen instalments - or 'volumes' over the period 2015-2017. In connection to this, our study investigates whether stock market investors responded positively and/or swiftly to the EPP. In order to assess stock market responses, this study sources the values of stock prices from the Composite Stock Price Index (JCI) and from ten sectorial indices reporting the prices of shares in ten different sectors: agriculture, mining, basic industry, miscellaneous industry, consumer goods, real estate, infrastructure, finance, trade, and manufacturing. In order to assess whether the JCI and the sectorial indices reacted positively or negatively in response to the EPP announcements, this study tests the changes in Abnormal Return (AR) and Cumulative Abnormal Return (CAR) across the observed indices, both before and after the EPP announcements.

In order to progress this investigation, Section 2 provides a review of relevant background literature, which guides the development of the research hypotheses. Section 3 subsequently describes the methodology, the sample used, and the process of data collection. Further, Section 4 reports the research results and their discussion, whilst the conclusion in Section 5 summarises the main findings and implications of our inquiry.

\section{Theoretical background}

\subsection{Investment in real and in financial assets}

An investment is a commitment of money or other resources, undertaken with a view to obtain future profits (Acharya \& Oncu, 2013; Bodie, 2014; Klein \& Shambaugh, 2015). Resources that may be committed to an investment fall into two main categories: real assets and financial assets. Real assets may consist of land, houses, machinery, gold, and even knowledge that might be used to produce goods and services. Instead, financial assets may come, for instance, in the form of stocks or bonds, which can be represented by a piece of paper or an electronic recording. In a narrower sense, therefore, investment is the employment of financial means to generate more revenue (Afonso \& Sousa, 2011; Gumanti, 2013; Agnello \& Sousa, 2013). Typically, investors seeking certainty of return will opt for low-risk investments, such as deposits or government bonds, which come with a guaranteed return of a relatively small magnitude (Zubir, 2011; Huyghebaert \& Xu, 2013; Huang \& Zhu, 2015). It is the disposition to commit resources to risky investments that determines the extent of return an investor will be capable of receiving (Li, 2009; 2012; Gertler \& Karadi, 2011). Another taxonomy concerning investment has to do with the manner of committing one's resources to an economic venture. An investor may do so directly, i.e. by buying and selling the assets from which he or she aims to reap a profit. Alternatively, he or she may indirectly place funds into companies or mutual funds, so as to hold a portfolio of securities (Bech \& Atala, 2010; Huyghebaert \& Xu, 2013; Huang \& Zhu, 2015). Capital markets offer two main kinds of securities, namely (i) fixed income securities, such as bonds issued by treasuries, government agencies, municipal authorities, and corporations; and (ii) equity, which can be distinguished into preferred and common stock. When investments are sold, they lead to a cash inflow. If the difference between the sale price and the original purchase price is positive, then the investment has produced a capital gain; if it is negative, it will have generated a capital loss (Tapia, 2017; Korinek, 2018). Zubir (2011) clarifies that shares are proofs of ownership of a company, meaning that, if the company is profitable, then shareholders will be entitled to the distribution of profits or dividends in proportion to every shareholder's degree of ownership. The return a shareholder obtains from the distribution of company profits is termed 'dividend yield'. In addition, stocks can also be traded on the secondary market, for a price that may be higher or lower than the original purchase price. The aggregate return from an investment in shares will eventually be measured by the dividend yield, plus any capital gains from resale on the secondary market. 


\subsection{Formation of stock prices}

Price formation in capital markets occurs through the balancing of supply and demand. Weston and Copeland (2010) attempts a taxonomy of factors that might influence stock price movements, which include: the expected yield from a share investment, when compared with its historical yield; risk levels connected to profit expectations; the proportion of corporate debt to equity; and dividend distribution policies. Exogenous variables might also influence stock price movements, such as wider economic activity, tax policy, and the overall movement of the stock market (Samila \& Sorenson, 2010; Rapetti, 2013; Rey, 2015; Oet \& Ong, 2016). Share prices on the stock market are volatile. However, this condition of fluctuating prices is precisely what allows a potential profit to be made, whenever market participants manage to determine which stocks might be undervalued, and are therefore likely to undergo future price increases. Thus, the likelihood of making a profit depends on investors' knowledge of exogenous and endogenous factors influencing stock prices (Alwi, 2003), which, in turn, justifies the adoption of various methods that might aid in predicting target stock prices. Samsul (2016) distinguishes models for estimating stock prices into three main categories, namely: ratio-based, discounted, and factor model approaches. The ratio-based approach seeks to determine the target price of shares based on the price/earnings ratio, the price/book value ratio or the price/dividend ratio. The discounted approach seeks to arrive at a target price by discounting either earnings or dividends, whereas factor models might assess target prices as a function of a single factor, a single index model, or a multifactor model. Finally, a stock price index is an indicator that describes the movement of stock prices. The Indonesian Stock Exchange features various types of indices, including the following: the Composite Stock Price Index (JCI), the Sectorial Index, the LQ45 Index, and the Jakarta Islamic Index (JII), among others. In addition, the classification of company sectors adopted on the Indonesia Stock Exchange is illustrated by Gumanti (2013).

\subsection{The relationship between information and stock price movements}

News convey information that is susceptible of affecting stock market prices (Harjito dan Martono, 2012). For instance, significant non-economic events, such as elections and international conflicts, generate repercussions on stock markets (Cutler et al., 1989). A comprehensive study by Neiderhoffer (1971) has scrutinised a large sample of events between 1950 and 1966, examining the correlation between the largest stock market movements of the period and significant news reports that were disseminated at the same time. The study subsequently investigates the ensuing effects in terms of price movements, concluding that stock markets are broadly responsive to economic, military and political policies. In connection to this, the efficiency of capital markets depends on the speed and accuracy with which they are able to absorb and reflect relevant information in the prices of securities (Harjito dan Martono, 2012). Malkiel and Fama (1970) distinguish between different kinds of information that are relevant for efficient price formation in capital markets, namely past stock prices, published information, and insider information.

Kendall (1953) has submitted that stock price patterns cannot be rationally predicted, when they display random fluctuations by virtue of being influenced by crowd psychology or 'animal spirits' that do not follow logical rules. He argues that stock prices might fluctuate randomly because, ordinarily, any price movements depend on the processing of new information, and it cannot be predicted when that new information - which could impact markets positively or negatively - will hit. Indeed, once all existing information has been disseminated and processed in the share price, it will not be practically possible to guess future variations, because new information cannot be logically anticipated. When stock prices nevertheless display fluctuations irrespective of the presence or the absence of new information, those changes will be irrational and reflect emotional reactions caused by psychological drives or 'animal spirits'. Such fluctuations interfere with the informational content of prices, and will be corrected in the future. However, controlling for random fluctuations, changes in stock prices will follow a particular direction of flow or trend. If this trend can be predicted, investors would reap returns exceeding the average market return (Bruno \& Shin 2015). Bad news are news that have a negative impact on stocks, causing a decrease in stock prices. Examples of bad news would be a drastic increase in bank interest 
rates, or increases in fuel prices, among others (Gennaioli et al., 2014; Avino \& Cotter, 2014; Kung, 2015; Engler \& Große-Steffen, 2016; Vegh, 2017; Korinek, 2018). Examples of good news, which cause prices to rise, would be a sharp increase in sales, a reduction in lending rates, or an expansion of business operations (Gali, 2015). Finally, some news have more ambiguous impacts: an increase in foreign exchange rates might be seen as very profitable by export companies, but detrimental to import companies. Beyond crowd investor psychology, bad news and good news, stock market prices may also incorporate the results of investor analysis (Wilson \& Baack, 2012; Sui \& Baum, 2014; Sousa \& Tan, 2015; Surdu \& Mellahi, 2016). The strength of capital markets' efficiency has been arranged in a hierarchy, based on the difference between capital markets that are operationally (internally) efficient, and capital markets that are efficient at fulfilling the task of price discovery (Jogiyanto, 2003). Malkiel and Fama (1970) illustrated this hierarchy by distinguishing between (i) strongly efficient markets, where the difference between market prices and 'true' (intrinsic) prices is very small. This will occur when investors have information that is relatively homogeneous, with the asking and buying prices not differing much, based on rationally foreseeable fundamentals. Below this first kind would be (ii) weakly efficient markets, where the difference between market and intrinsic prices will be larger because investors have limited information at their disposal, and trading will also reflect strong irrational movements. Finally, Fama also theorises the existence of (iii) perfect markets, where market prices and intrinsic prices coincide. However, in reality, there is no market for which this condition holds. This notwithstanding, in a strongly efficient market, prices reflect more complete information than in the presence of semi-strong market efficiency, which will in turn exceed the informational value of prices in a weakly efficient market. When a market only displays weak efficiency, stock price fluctuations will be very high and afford investors with the opportunity to obtain greater profits than those that might be obtained from speculating on a strongly efficient market.

\subsection{Types of stock return}

Return denotes the economic outcome of an investment. It can be actual, when it has already materialised, or expected, when it hasn't yet materialised, but is expected to occur in the future. Jogiyanto (2003) further clarifies this distinction by specifying that realised returns consist in income obtained by investors when their shares yield high dividends and positive capital gains on the stock market, and can be routinely calculated based on historical data. Instead, expected returns are projected into the future, but have not yet occurred. When investors obtain returns that are not in accordance with expectations, the difference between the expected return and the actual return is called Abnormal Return (AR). Abnormal returns may have their basis in discrete events, such as: national holidays, the beginning of a new calendar month, uncertain political atmosphere, extraordinary events, stock splits, and initial public offerings (IPOs), among others. Mathematically, Tandelilin (2010) provides the following formula for Abnormal Return (AR): $A R_{i, t}=R_{i, t}-E\left(R_{i, t}\right), A R_{i, t}=$ Abnormal Return of stock $i$ in period $t, R_{i, t}=$ Actual Return of stock $i$ in period $t$ and $E R_{i, t}=$ Expected Return of stock $i$ in period $t$

Building on this formula, the sum of entries for Abnormal Return over a period of time additionally yields the Cumulative Abnormal Return (CAR). Figure 1 below offers a succinct illustration of how the foregoing considerations are leveraged in the framework for this study.

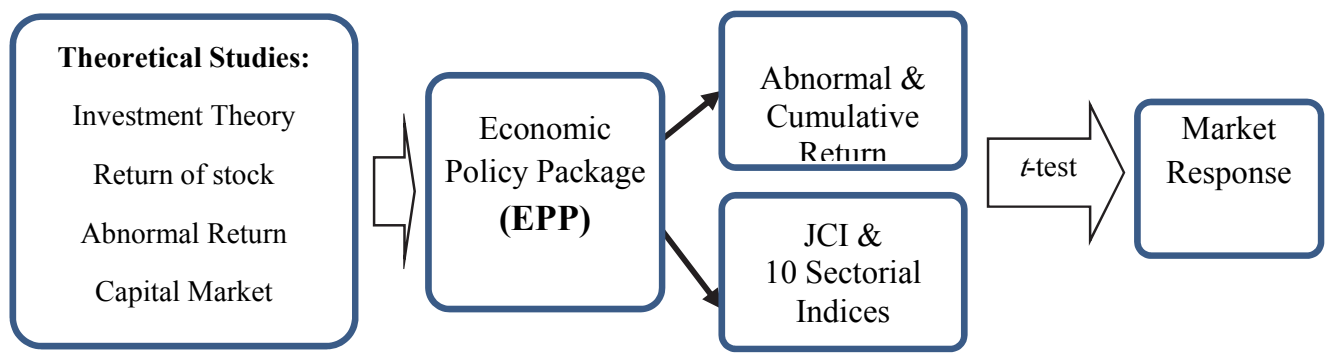

Fig. 1. Research theoretical framework 
Specifically, $t$-tests will be used to assess the market response to the EPP announcements, after tracking AR and CAR on the JCI and ten sectorial indices, in order to gauge whether the Indonesian government's announcement of several instalments of its EPP constituted an event that the Indonesian capital market priced favourably. Beyond providing feedback on the instant effect of economic policy announcements in Indonesia, this framework also demonstrates a rapid test to assess whether a particular policy announcement disrupts the expectations of market participants, in such a way as to lead to immediate adjustments.

\subsection{Hypothesis development}

In order to verify this theoretical question concerning the Indonesian capital market's reception and processing of information concerning the EPP, our research tests the following hypotheses:

$\mathrm{H}_{1}$ : There is a difference between the Abnormal Return (AR) of the firms listed in JCI before and after the EPP announcements.

This hypothesis directly tests whether economic policy announcements by the government yielded repercussions on the corporate business environment, mediated by stock market pricing mechanisms. According to the theoretical perspectives discussed previously, investors react to economic policy announcements through their trading decisions to buy or sell in the stock market. However, should this hypothesis be resolved in the negative, it would show that the sort of information provided by the EPP was not relevant to the point of significantly affecting traders' buy and sell decisions on the stock market.

$\mathrm{H}_{2}$ : There is a difference between the Cumulative Abnormal Return (CAR) of the firms listed in JCI before and after the EPP announcements.

This additional hypothesis complements the first. Indeed, if a particular kind of information affects the market, its repercussions might also compound over a period of time, leading to a higher or lower return on shares, than would be expected in the absence of that information.

$\mathrm{H}_{3}$ : There is a difference between the Abnormal Return (AR) of the firms listed in the sectorial indices before and after the EPP announcements.

This hypothesis tests whether information concerning the EPP might have had a more specific impact on particular economic sectors. Indeed, it might be the case that government policy announcements produce a discernible impact only on the specific sectors concerned by those policies. This would be visible on the sectorial indices, whereas a response limited to stocks of one commercial sector might get cancelled out on a market-wide index like the JCI.

$\mathrm{H}_{4}$ : There is a difference between Cumulative Abnormal Return (CAR) of the firms listed in the sectorial indices before and after the EPP announcements.

This final hypothesis complements the one immediately preceding it. Namely, if it were the case that EPP announcements affected one commercial sector more than others, this might also be visible through a cumulative deviation from returns to be expected in the absence of that information.

\section{Methodology}

\subsection{Research methods}

In order to find out the market response to announcements of Indonesia's EPP, this article uses a quantitative approach for processing stock price index data, which is common in the literature (Tandelilin, 
2010; Agnello \& Sousa, 2013; Gupta et al., 2014). In particular, an event study method is used to observe the impact of announcements of economic or political value, and how quickly information is processed and incorporated into market prices (Samsul, 2016). According to Fama (1991), an event study aims to see how quickly the prices of securities reflect information that has become public, and it also aims to investigate the market reaction to information about an event that has entered the public domain. This can help one assess both the informational value of the event, as well as to gauge the rapidity of markets at processing information, helping to assess whether they are efficient in at least semi-strong from.

\subsection{Population and samples}

The population, with respect to the event investigated by this study, consists of sixteen volumes of Indonesia's EPP issued during three years of Joko Widodo's tenure as President of Indonesia, during the period 2015-2017. Within this population, a sample of three instalments or 'volumes' has been selected, namely volumes I, X, and XVI. The EPP is a set of measures launched by the Indonesian government, in a bid to facilitate business activity and lure more investment to the country. Its initial adoption occurred amidst a global and domestic economic downturn (Sudana \& Harlanta, 2018). The first volume (I) was announced on 9 September 2015, and carried measures concerning the ease of business licensing and a simplification of rules, pursuing a policy of deregulation to improve the domestic business climate. The second volume (II) was launched after a few weeks from the first, on 29 September 2015, and was more related to incentivising investment in the capital market. On 7 October 2015, the government released the third volume (III) of the EPP, aiming to decrease certain prices. One week after that, the government announced a fourth volume (IV) of the EPP, concerning the regularisation of the payroll system in Indonesia. Further instalments were also released in the same year. Instead, on 11 February 2016, the tenth volume $(\mathrm{X})$ was promulgated, removing the foreign ownership cap on thirty-five business sectors, and implementing further protection for small and medium enterprises, as well as cooperatives. Over a year later, on 31 August 2017, the government announced the sixteenth volume (XVI), which aimed to boost investment and economic growth in Indonesia. Amidst this population of different announcements, this study investigates capital market response in connection to a purposive ample of three, namely EPP volume I (9 September 2015), EPP volume X (11 February 2016), and EPP volume XVI (31 August 2017).

\subsection{Data analysis techniques}

This study undertakes $t$-test to investigate the effect of the announcement of different volumes of the EPP on the JCI and the sectorial indices. Testing of AR aims to ascertain the statistical significance of abnormal returns during the event window (Yusuf et al., 2009; Jogiyanto, 2003, 2008, 2010, 2015; Zulfikar \& Ade Mayvita, 2017), which will be positive for news deemed good, and negative for news deemed bad. In order to gauge the impact on AR and CAR of economic policy announcements, as tracked by the JCI and sectorial indices, the following formula has been adopted:

$$
A R S=\frac{A R_{i, t}}{K S E_{t}}
$$

where

ARS $=$ standardised Abnormal Return $i$ on the $t$-day of the event window

$\mathrm{Ar}_{\mathrm{i}, \mathrm{t}}=$ Abnormal Return $i$ on the $t$-day of the event window

$\mathrm{KSE}_{\mathbf{t}}=$ standard error of estimate $(\sigma)$

In order to repeat the same analysis on CAR, the $t$-test has been carried out on Cumulative Average Abnormal Return (CAAR) defined as follows:

where

$$
C A A R S=\frac{C A A R}{K S E_{C A A R}}
$$


CAARS $=$ standardised average cumulative abnormal return in the estimation period

$\mathrm{CAAR}=$ average cumulative abnormal return in the estimation period

$\mathrm{KSE}=$ standard error of estimate $(\sigma)$

A paired two-tailed test was carried out on the $t$-test statistics before and after the announcement of the EPP, both with respect to the JCI and the sectorial indices.

\section{Results and discussion}

The expected return is obtained by calculating the average during the estimation period using the Mean Adjusted Model method, as shown in Table 1 below.

Table 1

Expected return of EPP (volume I, volume X, and volume XVI)

\begin{tabular}{lccc}
\hline \multirow{2}{*}{ Index } & \multicolumn{3}{c}{ Expected Return } \\
\cline { 2 - 4 } & Volume I & Volume X & Volume XVI \\
\hline JCI & -0.0048 & -0.0010 \\
Agriculture & -0.0109 & 0.0010 & -0.0021 \\
Mining & -0.0078 & -0.0019 & -0.0032 \\
Basic Industry & -0.0097 & -0.0004 & -0.0018 \\
Miscellaneous Industrial & -0.0065 & 0.0014 & 0.0006 \\
Consumer Goods & -0.0030 & -0.0003 & 0.0011 \\
Real Estate & -0.0055 & 0.0012 & 0.0006 \\
Infrastructure & -0.0046 & 0.0004 & 0.0004 \\
Finance & -0.0040 & -0.0008 & 0.0000 \\
Trade & -0.0031 & 0.0000 & -0.0010 \\
Manufacture & -0.0053 & 0.0010 & \\
\hline
\end{tabular}

Source: Author processed data, 2018

\subsection{EPP volume I: 26 August 2015 - 23 September 2015}

With respect to the announcement of EPP volume I, all return values are lower than the abnormal return value over the estimation window. The expected return value is negative -0.0048 . Returns and abnormal returns display a fluctuating movement, with the highest daily AR value on day t-9 of 0.0504; after the event, the market gives a quick positive response to the announcement of EPP volume I. The movement of return and abnormal return indicates that, after processing information on the impact of the EPP, the market corrects its expectations (Rapetti, 2013; Kung, 2015; Georgiadis, 2016; Tapia, 2017). Tandelilin (2010) and Harjito dan Martono (2012) define a 'fast' market reaction when prices adjust within two days of the event, and settle on the third day after the event, reaching a new equilibrium (Fig. 2).

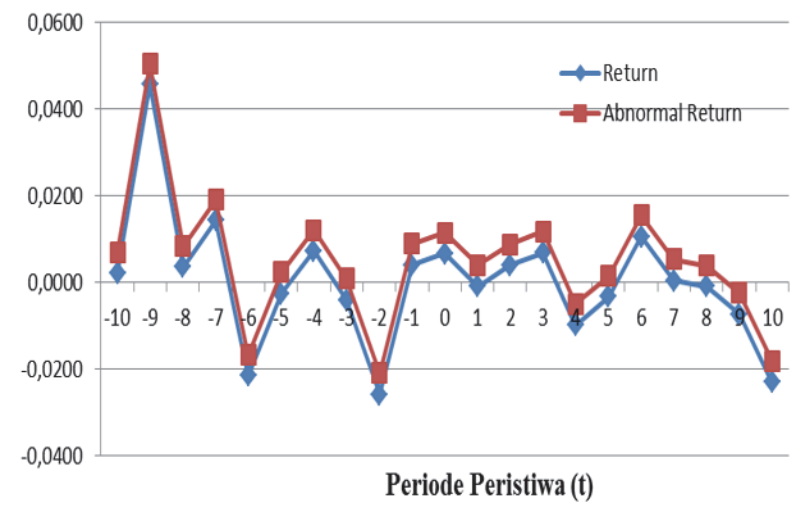

(a)

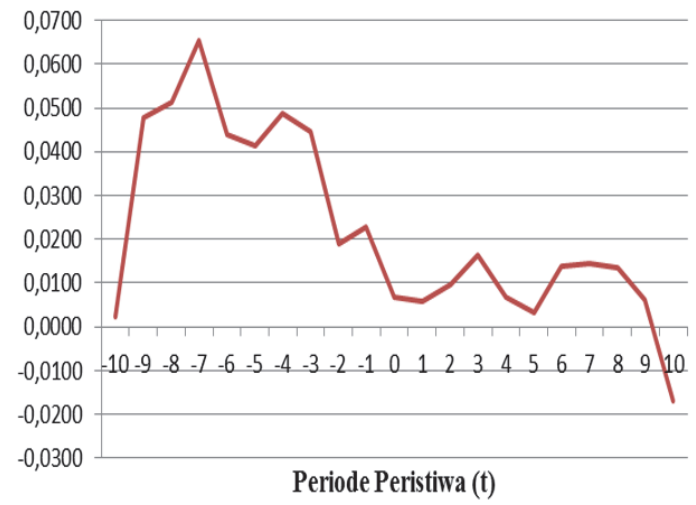

(b)

Fig. 2. Movement of (a) Return and Abnormal Return and (b) Cumulative Return on JCI for EPP volume I The CAR value before the event was $2.2 \%$, which decreased to $-1.7 \%$. This shows that the cumulative 
announcement of the EPP volume I elicited an overall negative reaction by the stock market (Fig. $2 \mathrm{~b}$ ).

\subsection{EPP volume X: 27 January 2016 - 25 February 2016}

With respect to the announcement of EPP volume $X$, the expected return value is 0.0004 . The movement of return and abnormal return is illustrated in Fig. 3, displaying upward and downward fluctuations before the announcement, and with the highest daily return value on day t-3 at 0.0281 . After the announcement, the market rapidly provided a positive response to EPP volume $\mathrm{X}$.

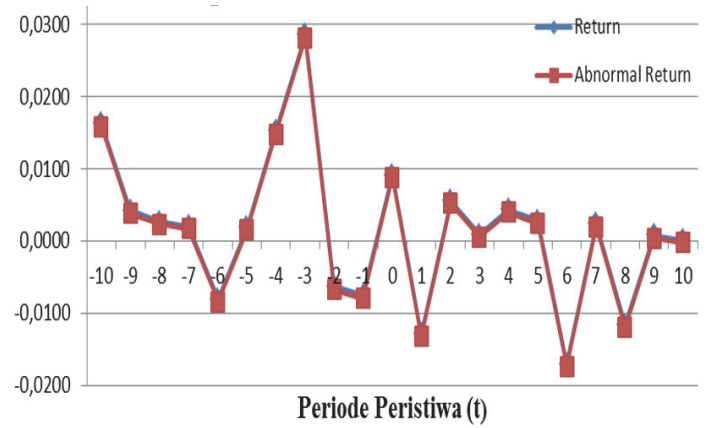

(a)

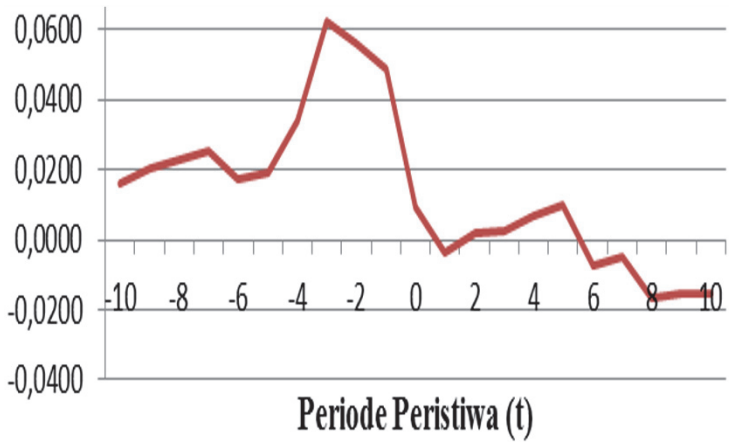

(b)

Fig. 3. Movement of (a) Return and Abnormal Return and (b) Cumulative Return on JCI for EPP volume X

The CAR value before the event is $2.2 \%$ and decreases to $-1.7 \%$ afterwards, which means that the announcement of EPP volume $\mathrm{X}$ was responded to in the negative by capital markets (Fig. 3b).

\subsection{EPP volume XVI: 16 August 2017 - 15 September 2017}

The movement of return and abnormal returns is portrayed in Fig. 4. Before the event, the return and abnormal return values fluctuate, and at $\mathrm{t}+1$ there is a decrease in AR. This means that the market responds quickly to the announcement of EPP volume XVI. However, this decrease is corrected at $\mathrm{t}+1$ and then rises again at $\mathrm{t}+2$. The CAR value before the event is $2.28 \%$, which decreases after the event to $1.69 \%$, again meaning that the announcement of EPP volume XVI elicited a negative response by the market (Fig. 4).

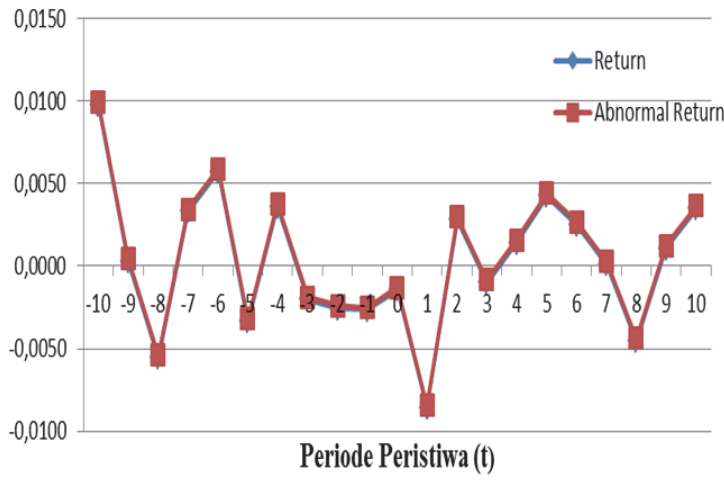

(a)

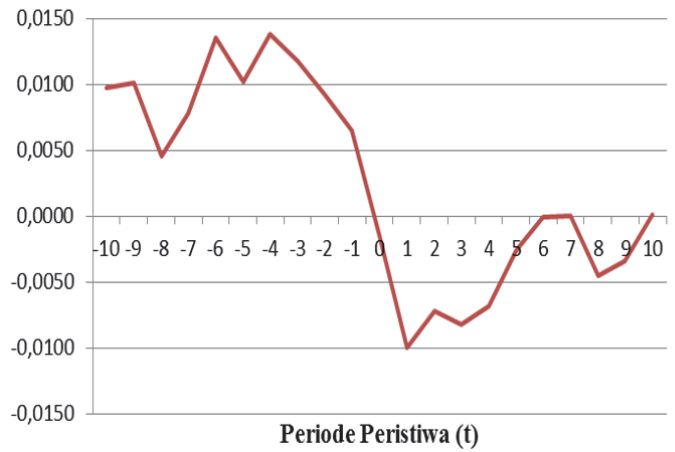

(b)

Fig. 4. Movement of (a) Return and Abnormal Return and (b) Cumulative Return on JCI for EPP volume XVI

\subsection{Hypothesis test results}

In view of the foregoing, the aforementioned effects were tested for statistical significance, in order to 
ascertain whether EPP announcements elicited a discernible response, and one that caused markets gradually to adjust to new information.

\subsubsection{Test of Hypothesis H1: Abnormal Return (AR) on the JCI}

$\mathrm{H}_{1}$ concerns the impact of EPP announcements on AR in connection with JCI values, which is not statistically significant in connection with volumes I, X, and XVI. This means that, on aggregate, EPP announcements did not produce an appreciable difference in the price movements of JCI-listed securities.

\subsubsection{Test of Hypothesis H2: Cumulative Abnormal Return (CAR) on the JCI}

A paired $t$-test of two samples for means was conducted to test whether there were differences in CAR before and after EPP announcements, in connection to volumes I, X and XVI. Table 2 reports the following results: at EPP volume I, the CAR value decreases from 0.0653 to 0.0079 , meaning that the market reacts negatively to the announcement. In connection to EPP volume $\mathrm{X}$, the value of CAR decreases from 0.0301 to -0.0048 , meaning that the market also reacts negatively. Finally, in connection to EPP volume XVI, the CAR value decreases from 0.0106 to 0.0001 , revealing another negative reaction.

Table 2

Paired $t$-test of two samples for means of CAR on JCI (volume I, volume X, and volume XVI)

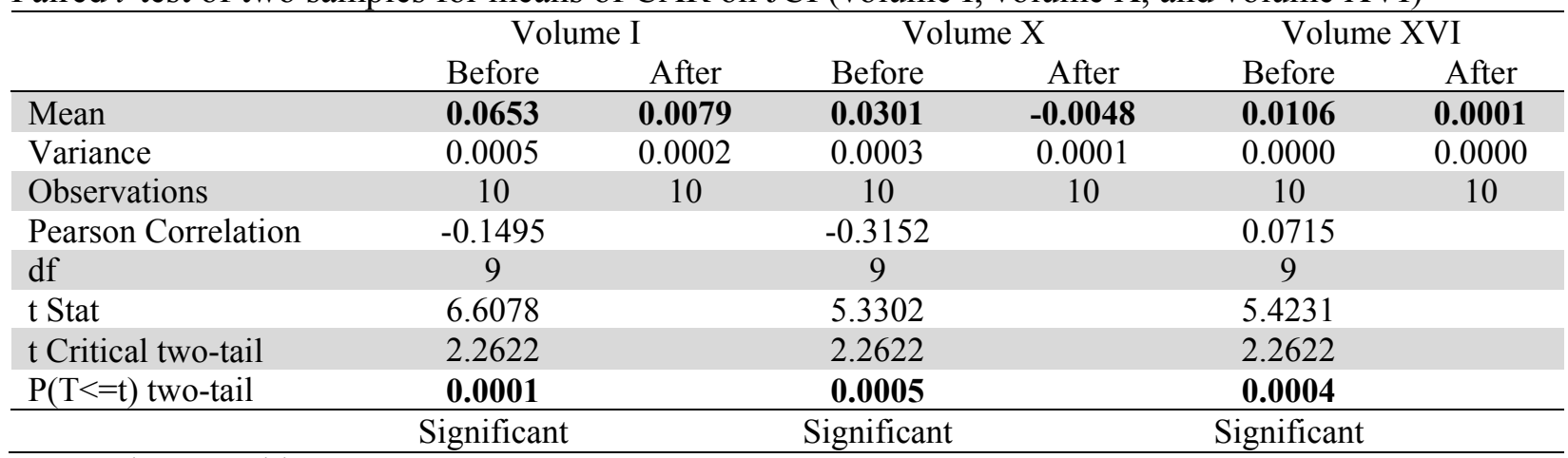

Source: Author processed data, 2018

What the above shows is that prices reacted through a downward movement to each of the three EPP announcements, with differences before and after the event being statistically significant. This means that the EPP was, on aggregate, responded to negatively by the capital market.

\subsubsection{Test of Hypotheses H3: Abnormal Return (AR) on the sectorial indices}

The statistical analysis in connection to AR on the sectorial indices (H3) shows that only a few sectors display a significant reaction to EPP announcements. Specifically, for volume I, only the agriculture and basic industry sectors assessed that the announcements conveyed relevant informational content. The fact that those sectors were able to process the EPP announcement also reveals semi-strong efficiency for the purpose of incorporating new information in new prices, according to the categorisation connected to the efficient market hypothesis (Fama, 1991). For EPP volume X, only the agriculture sector reacted to the information content of the EPP announcement and, finally, in connection to volume XVI, the agriculture sector and the basic industry processed the informational content of the announcement.

\subsubsection{Test of Hypothesis H4: Cumulative Abnormal Return (CAR) on the sectorial indices}

Testing for $\mathrm{H}_{4}$ offers a more nuanced view than the test for CAR in connection to the JCI. Indeed, the market reaction, once broken down by economic sector, is more complex. In connection with EPP vol- 
ume I, the government sought (i) to encourage the competitiveness of national industries through deregulation, de-bureaucratisation, more effective law enforcement, and improved business certainty; (ii) to accelerate national strategic projects by removing various obstacles (simplifying licensing, completing spatial planning and providing land, accelerating public procurement for goods and services, allowing discretion for addressing business difficulties, enhancing legal protection, and supporting regions to accelerate national strategic projects) and (iii) to increase investment in the real estate sector by issuing policies in support of housing development, especially for low-income communities, alongside greater investment opportunities in real estate. On the basis of this information, four economic sectors showed a positive response (agriculture, mining, infrastructure, and trade) that was also statistically significant, whereas the other six sectorial indices decreased over time (Table 3).

Table 3

CAR before and after events, and paired $t$-Test of two Samples for means of CAR on sectorial indices (volume I, volume X, and volume XVI)

\begin{tabular}{|c|c|c|c|c|c|c|}
\hline Sectorial Index & Before & After & Volume I & Volume X & $\begin{array}{c}\text { Volume } \\
\text { XVI }\end{array}$ & Sig. \\
\hline \multirow[t]{3}{*}{1 Agriculture } & 0.1360 & 0.1573 & Up & & & $*$ \\
\hline & 0.0175 & -0.0107 & & Down & & $*$ \\
\hline & 0.0013 & 0.0402 & & & Up & ns \\
\hline \multirow[t]{3}{*}{2 Mining } & 0.1002 & 0.1148 & Up & & & $*$ \\
\hline & 0.0332 & 0.0525 & & Up & & $* *$ \\
\hline & -0.0157 & -0.0719 & & & Down & ns \\
\hline \multirow[t]{3}{*}{3 Basic Industry } & 0.1973 & 0.1086 & Down & & & $*$ \\
\hline & 0.0475 & -0.0445 & & Down & & $*$ \\
\hline & -0.0328 & 0.0357 & & & Up & $* *$ \\
\hline \multirow[t]{3}{*}{$4 \quad$ Miscellaneous Industrial } & 0.1143 & 0.0323 & Down & & & $*$ \\
\hline & 0.0974 & -0.0343 & & Down & & $* *$ \\
\hline & 0.0299 & 0.0260 & & & Down & $*$ \\
\hline \multirow[t]{3}{*}{$\begin{array}{ll}5 & \text { Consumer Goods }\end{array}$} & 0.0429 & 0.0217 & Down & & & * \\
\hline & 0.0732 & -0.0046 & & Down & & $*$ \\
\hline & 0.0506 & 0.0403 & & & Down & $*$ \\
\hline \multirow[t]{3}{*}{$6 \quad$ Real Estate } & 0.0799 & 0.0492 & Down & & & $*$ \\
\hline & 0.0024 & 0.0108 & & Up & & ns \\
\hline & -0.0049 & -0.0343 & & & Down & ns \\
\hline \multirow[t]{3}{*}{7 Infrastructure } & 0.0210 & 0.0417 & Up & & & $*$ \\
\hline & 0.0316 & -0.0427 & & Down & & $*$ \\
\hline & -0.0033 & -0.0223 & & & Down & $*$ \\
\hline \multirow[t]{3}{*}{8 Finance } & 0.0791 & -0.0047 & Down & & & $*$ \\
\hline & 0.0273 & -0.0450 & & Down & & $* *$ \\
\hline & 0.0031 & -0.0105 & & & Down & $*$ \\
\hline \multirow[t]{3}{*}{9 Trade } & 0.0391 & 0.0418 & Up & & & $*$ \\
\hline & 0.0433 & 0.0029 & & Down & & $*$ \\
\hline & -0.0155 & -0.0022 & & & Up & ns \\
\hline \multirow[t]{3}{*}{10 Manufacture } & 0.0913 & 0.0424 & Down & & & $*$ \\
\hline & 0.0732 & -0.0159 & & Down & & $*$ \\
\hline & 0.0297 & 0.0370 & & & Up & ns \\
\hline
\end{tabular}

Note: ns: not significant, $*$ : significant $1 \%$;*: significant with $5 \%$

In connection to EPP volume X, its aim was to support small businesses, by issuing a Negative Investment List (DNI), i.e. a list of closed and open business fields, accompanied by specific investment requirements, with a view to (i) protect micro, small and medium enterprises, and cooperatives (MSMEs); (ii) address economic conflicts in certain sectors; (iii) reduce prices of certain essential goods such as 
drugs and medical devices; (iv) expand employment opportunities; and (v) strengthen the competitiveness of small businesses. In response to this, eight sectorial indices reacted negatively, with the only positive responses being recorded in the mining (statistically significant) and real estate (not statistically significant) sectors (Table 3). This shows that the capital market processed the announcement of EPP volume $\mathrm{X}$ carefully, and that almost all market participants across economic sectors responded negatively. Finally, EPP volume XVI sought to pursue the following goals: (i) to address emerging challenges in the policy implementation process; (ii) to incentivise the use of information technology through an integrated, single-submission business licensing system. A Presidential Regulation (PerPres) was issued to attain this second goal in two stages, starting with establishing a task force for escorting and resolving licensing barriers; implementing a checklist for business licensing in special economic zones, industrial areas, and tourism areas; and promoting data sharing in connection with licensing procedures. The second stage was meant to reform business licensing regulations, and finally to implement the single-submission integrated business licensing system.

In response to this volume of the EPP, four sectorial indices recorded a positive reaction, namely basic industry (statistically significant), alongside agriculture, trade and manufacturing (which were instead not statistically significant). This reflects that, in general, the market also responded negatively to EPP volume XVI, as can be gleaned from Table 3.

In view of the foregoing, $H 1$ has been rejected (EPP announcements were not capable of producing a significant change in returns on the JCI), whereas $\mathrm{H}_{3}$ was accepted for some sectors (showing that the EPP announcements were sufficient to sway prices only in some sectors). Instead, $\mathrm{H}_{2}$ and $\mathrm{H}_{4}$ yielded statistically significant results, which reveal that, on balance, all the three sampled volumes of the EPP led to decreasing returns. These results ought to be interpreted with a note of caution, especially by observing that the market response analysed in this study is the momentary market reaction to the information presented in an official economic policy. This is different to an assessment of the actual results that might have been brought about through implementation of that policy. The real results of economic policy cannot be processed in the immediate reaction of capital market actors, because a significant time lag is needed for the actual results of economic policy to be evaluated accurately (Gupta et al., 2014).

\section{Conclusion}

This research has undertaken an event study to illustrate the impact of government policy announcements on stock market returns. The events examined have been a sample of three different instalments or 'volumes' of the Economic Policy Package enacted between 2015 and 2017 by Indonesian President Joko Widodo, gauging their impact on market returns by following their influence on the values of the JCI and ten sectorial indices on the Indonesia Stock Exchange. In order to investigate this question, the study has formulated four hypotheses, testing the significance and direction of the impact of policy announcements on the Abnormal Return and on the Cumulative Abnormal Return over an estimation window. Testing for the effects of EPP announcements on AR in connection with the values of the JCI led to the result that the difference between expected returns and actual returns was not significant for all three EPP volumes (I, X, and XVI). Testing for the cumulative market response as gauged by CAR has shown that volume I was accompanied by a positive, if decreasing, CAR value, and EPP volumes X and XVI also displayed a downward response.

The statistical analysis in connection to AR on the sectorial indices shows instead that only a few sectors display a reaction to EPP announcements. Specifically, for volume I, only the agriculture and basic industry sectors assessed that the announcements had information content. For EPP volume X, the agriculture sector displayed a significant reaction and, in connection to volume XVI, the agriculture and the basic industry sectors displayed significant changes in AR. Statistical analysis for the cumulative effects of EPP announcements on individual sectors shows that volume I elicited durable reactions in the agri- 
culture, mining, infrastructure and trade sectors; positive effects were recorded in the mining and property sector for EPP volume X; and in the agriculture, basic industry, trade and manufacturing sectors for EPP volume XVI. Other economic sectors showed a negative CAR, which means that, on aggregate, almost all industrial sectors responded negatively to the government's EPP announcements.

The implication of this analysis is that the Indonesian financial market was generally able to process information connected to the EPP announcements, but that it did not ascribe to it a positive value in terms of higher expectations of returns. This might reveal an assessment that those government-issued policies did not provide sufficient incentives to remove challenges to the establishment of business operations across economic sectors. At the same time, a limitation of our analysis is that it only accounts for market reaction to the communication of a new policy, whilst it is not suitable to provide an assessment of the actual results of the policy. These can only be gauged through longitudinal studies that consider changes in real economic values, exploring connections between policy options and observed changes in key variables describing economic performance.

\section{References}

Acharya, V.V., \& Oncu, T.S. (2013). A proposal for the resolution of systemically important assets and liabilities: the case of the repo market. International Journal of Central Banking, 9(1), 291-350.

Afonso, A., \& Sousa, R.M. (2011). What are the effects of fiscal policy on asset markets?. Economic Modeling, 28(4), 1871-1890.

Agnello, L., \& Sousa, R. M. (2013). Fiscal policy and asset prices. Bulletin of Economic Research, 65(2), 154-177.

Alwi, H. (2003). Tata Bahasa Baku Bahasa Indonesia. Balai Pustaka, Jakarta.

Avino, D., \& Cotter, J. (2014). Sovereign and bank CDS spreads: Two sides of the same coin. Journal of International Financial Markets, Institutions, and Money, 32(C), 72-85.

Bech, M. L., \& Atalay, E. (2010). The topology of the federal funds market. Physica A: Statistical Mechanics and its Applications, 389(22), 5223-5246.

Berk, J., DeMarzo, P., \& Harford, J. (2012). Fundamentals of Corporate Finance, $2^{\text {nd }}$ ed., Prentice Hall, Upper Saddle River, NJ.

Bodie, K.M. (2014). Manajemen Portofolio dan Investasi. $9^{\text {th }}$ ed., Salemba Empat, Jakarta.

Bruno, V., \& Shin, H. S. (2015). Capital flows and the risk-taking channel of monetary policy. Journal of Monetary Economics, 71, 119-132.

Cutler, D., Poterba, J., \& Summers, L. (1989). What Moves Stock Prices? Journal of Portfolio Management, 15(3), 4-12.

Engler, P., \& Steffen, C. G. (2016). Sovereign risk, interbank freezes, and aggregate fluctuations. European Economic Review, 87, 34-61.

Malkiel, B. G., \& Fama, E. F. (1970). Efficient capital markets: A review of theory and empirical work. The Journal of Finance, 25(2), 383-417.

Fama, E.F. (1991). Efficient capital markets: II. Journal of Finance, 46(5), 1575-1617.

Gali, J. (2015). Monetary Policy, Inflation, and the Business Cycle: An Introduction to the New Keynesian Framework. $2^{\text {nd }}$ ed., Princeton University Press, Princeton, NJ.

Gennaioli, N., Martin, A., \& Rossi, S. (2014). Sovereign default, domestic banks, and financial institutions. The Journal of Finance, 69(2), 819-866.

Georgiadis, G. (2016). Determinants of global spillovers from US monetary policy. Journal of International Money and Finance, 67, 41-61.

Gertler, M., \& Karadi, P. (2011). A model of unconventional monetary policy. Journal of Monetary Economics, 58(1), 17-34.

Gumanti, T.A. (2013). Kebijakan Dividen Teori, Empiris Dan Implikasi. Sekolah Tinggi Ilmu Manajemen YKPN, Yogyakarta.

Gupta, R., Jooste, C., \& Matlou, K. (2014). A time-varying approach to analysing fiscal policy and asset prices in South Africa. Journal of Financial Economic Policy, 6(1), 46-63. 
Harjito dan Martono, A. (2012). Manajemen Keuangan. $2^{\text {nd }}$ ed., Ekonisia, Yogyakarta.

Huang, W., \& Zhu, T. (2015). Foreign institutional investors and corporate governance in emerging markets: Evidence of a split-share structure reform in China. Journal of Corporate Finance, 32, 312-326. Huyghebaert, N., \& Xu, W. (2015). What determines the market share of investment banks in Chinese domestic IPOs?. China Economic Review, 34, 150-168.

Jogiyanto, H. M. (2003). Teori portofolio dan analisis investasi. Yogyakarta: Bpfe.

Jogiyanto, H. (2008). Teori Portofolio dan Analisis Investasi. $5^{\text {th }}$ ed., Penerbit BPFE, Yogyakarta.

Jogiyanto, H. (2010). Teori Portofolio dan Analisis Investasi, $7^{\text {th }}$ ed., BPFE, Yogyakarta.

Jogiyanto, H. (2015). Teori Portofolio dan Analisis Investasi, $10^{\text {th }}$ ed., Penerbit BPFE, Yogyakarta.

Kendall, M.G. (1953). The Advanced Theory of Statistics, Vol. 1, Griffin, London.

Klein, M. W., \& Shambaugh, J. C. (2015). Rounding the corners of the policy trilemma: sources of monetary policy autonomy. American Economic Journal: Macroeconomics, 7(4), 33-66.

Korinek, A. (2018). Regulating capital flows to emerging markets: An externality view. Journal of International Economics, 111, 61-80.

Kung, H. (2015). Macroeconomic linkages between monetary policy and the term structure of interest rates. Journal of Financial Economics, 115, 42-57.

Li, X. (2009). China's regional innovation capacity in transition: An empirical approach. Research Policy, 38, 338-357.

Li, X. (2012). Behind the recent surge of Chinese patenting: An institutional view. Research Policy, 41, 236-249.

Neiderhoffer, V. (1971). The analysis of world events and stock prices, Journal of Business, 44(2), 193 219.

Oet, M. V., \& Ong, S. J. (2016). From organization to activity in the US collateralized interbank market. Research in International Business and Finance.

Rapetti, M. (2013). Macroeconomic policy coordination in a competitive real exchange rate strategy for development. Journal of Globalization and Development, 3(2), 1-31.

Rey, H. (2015). Dilemma not Trilemma: the Global Financial Cycle and Monetary Policy Independence. Working paper, National Bureau of Economic Research.

Samila, S., \& Sorenson, O. (2010). Venture capital as a catalyst to commercialization. Research Policy, 39, 1348-1360.

Samsul, M. (2016). Pasar Modal dan Manajemen Portofolio, $2^{\text {nd }}$ ed., Erlangga, Jakarta.

Sousa, C.M.P., \& Tan, Q. (2015). Exit from a foreign market: Do poor performance, strategic fit, cultural distance, and international experience matter?. Journal of International Marketing, 23(4), 84-104.

Sudana, I. M., \& Harlanta, A. (2018). Stock Market Reaction to the Announcement of the 2015 Indonesian Government Economic Policy Package in the Indonesia Stock Exchange. KnE Social Sciences, 3(10).

Sui, S., \& Baum, M. (2014). Internationalization strategy, firm resources and the survival of SMEs in the export market. Journal of International Business Studies, 45(7), 821-841.

Surdu, I., \& Mellahi, K. (2016). Theoretical foundations of equity based foreign market entry decisions: A review of the literature and recommendations for future research. International Business Review, 25(5), 1169-1184.

Tandelilin, E. (2010). Portofolio dan Investasi Teori dan Aplikasi, $1^{\text {st }}$ ed., Kanisius, Yogyakarta.

Tapia, M. (2017). Challenges to monetary policy in a small open economy, paper presented at the Are we Heading for a New Monetary Order and New Monetary Policy Regime? Roundtable, 5 September, Vienna.

Vegh, C.A. (2017). The monetary policy dilemma in LAC: coming back to a Central Bank near you. Paper presented at the 9th Annual Conference of the Central Reserve Bank of Peru and the Reinventing Bretton Woods Committee, 24-25 July 2017, Cuzco, Peru.

Weston, J. F., \& Copeland, T. E. (2010). Manajemen Keuangan, Binarupa Aksara, Jakarta.

Wilson, R. T., \& Baack, D. W. (2012). Attracting foreign direct investment: Applying Dunning's location advantages framework to FDI advertising. Journal of International Marketing, 20(2), 96-115.

Yusuf, S.D, Atim, D., \& Harry S. (2009). Analisis reaksi investor terhadap pengumuman right issue di 
Bursa Efek Jakarta', Wacana, 12(4), 792-814.

Zubir, Z. (2011). Manajemen Portofolio: Penerapannya dalam Investasi Saham. Salemba Empat, Jakarta.

Zulfikar, R., \& Ade Mayvita, P. (2017). The effects of political events against abnormal return and total volume sharia shares activity that listed in Jakarta Islamic Index (JII). Jurnal Ilmiah Bidang Akuntansi dan Manajemen, 14(2), 157-168.

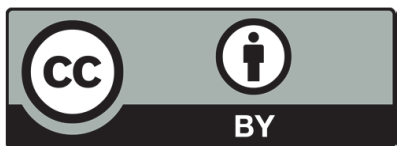

(C) 2019 by the authors; licensee Growing Science, Canada. This is an open access article distributed under the terms and conditions of the Creative Commons Attribution (CCBY) license (http://creativecommons.org/licenses/by/4.0/). 